\section{Déterminants de la structure des communautés fongiques dans les forêts de Corse : rôle des perturbations et de la composition forestière}

\section{Adrien TAUDIÈRE}

\section{RÉSUMÉ}

L'étude de l'écologie des micro-organismes est récente malgré son importance pratique et théorique intrinsèque, mais également son rôle central dans la niche des macro-organismes. Les interactions plantes-champignons, de par leur importance socio-écologique et leur diversité du mutualisme au parasitisme en passant par le commensalisme -, offrent un modèle judicieux pour étudier l'écologie des communautés de micro-organismes en interaction avec des macro-organismes.

À l'aide de techniques de séquençage à haut débit (NGS) et d'analyse des réseaux, nous explorons certains déterminants de la structure des champignons des forêts de Corse à travers trois guildes : les champignons ectomycorhiziens, endophytiques et saprotrophes. Ce travail considère les processus de dispersion, les perturbations (feux et chablis), les facteurs environnementaux (par exemple la profondeur du sol) et les contraintes dérivées de l'interaction avec les hôtes (par exemple la taxinomie). Les assemblages des communautés des différentes guildes présentent des patrons communs qui pourraient être issus de mécanismes identiques. Ainsi, l'ensemble des guildes étudiées présentent des variations fortes à l'échelle des microrégions de Corse et entre forêts ayant des histoires de feux différentes. En revanche, l'importance des différents processus d'assemblage et les échelles spatiales auxquelles ils s'appliquent varient selon les guildes. Nous discutons des implications que suscite ce travail pour les écologues des communautés et pour les gestionnaires d'espaces naturels.

Mots-clés : champignons, mycorhizes, régime de feu, écologie des communautés, chablis, décomposition, Pinus nigra subsp. laricio, forêt mixte, Corse, Méditerranée, France.
Drivers of fungal community composition in Corsican forests: role of disturbance and plant composition

\section{ABSTRACT}

Studies of the ecology of micro-organisms began only recently despite their intrinsic importance - both practical and theoretical - and their central role in forming the niche habitats of macro-organisms. Plant-fungi interactions offer a relevant model for studies of the ecology of micro-organisms interacting with macro-organisms because of their considerable ecological and economic value as well as their high taxonomic and ecological diversity.

Using next-generation sequencing (NGS) and network analysis, we explored some of the drivers of fungal community composition in Corsica, at various scales and in three ecological guilds: ectomycorrhizal, endophytic and saprotrophic fungi. We investigated the effects on fungal communities of disturbance (e.g. fire and treefall), environmental variables (e.g. soil depth), constraints due to interactions with host plants (e.g. taxonomy) and dispersion. Some patterns of community assembly are similar across guilds and may be governed by the same mechanisms. We found wide variations in fungal communities at the micro-regional scale among the guilds studied and between forests with a different history of wildfires. However, the relative importance of assembly processes and the spatial scales at which they occur vary across guilds. In Corsican pine forests, fifteen years after a fire, the diversity of soil fungus is close to the diversity in unburned stands. Despite the absence of effects on diversity, fire produces clear shifts in the composition of soil fungus communities, in particular for saprobic fungi. We discuss the implications of these findings for plant and fungal community ecologists and for managers of natural areas.

Keywords: fungi, mycorrhiza, fire regime, community ecology, canopy gaps, decomposition, Pinus nigra subsp. laricio, mixed forest, Corsica, Mediterranean, France.
Determinantes de la estructura de las comunidades fúngicas en los bosques de Córcega: rol de las perturbaciones y de la composición forestal

\section{RESUMEN}

Pese a su intrínseca importancia práctica y teórica, el estudio de la ecología de los microorganismos $-\mathrm{y}$ su papel central en el nicho de los macroorganismos- es reciente. Las interacciones planta-hongo, por su importancia socioecológica y su diversidad -del mutualismo al parasistismo pasando por el comensalismoproporcionan un modelo adecuado para estudiar la ecología de las comunidades de microorganismos en interacción con macroorganismos. Mediante técnicas de secuenciación de nueva generación (NGS) y análisis de redes, exploramos algunos determinantes de las estructura de los hongos de los bosques de Córcega a través de tres gremios: los hongos ectomicorrícicos, endofítos y saprófitos. Este trabajo tiene en cuenta procesos de dispersión, perturbaciones (incendios y chablis), factores ambientales (la profundidad del suelo, por ejemplo) y limitaciones derivadas de la interacción con los hospedantes (la taxonomía, por ejemplo). Los ensamblajes de comunidades de los distintos gremios siguen pautas comunes que podrían originarse según unos mismos mecanismos. Así pues, todos los gremios estudiados muestran importantes variaciones a nivel de las microrregiones de Córcega y entre bosques con distintos antecedentes de incendios. En cambio, la importancia de los distintos procesos de ensamblaje y las escalas espaciales a las que se aplican varían según los gremios. Se analizan las repercusiones de este trabajo para los ecólogos de comunidades y los gestores de espacios naturales.

Palabras clave: hongos, micorrizas, régimen de incendios, ecología de comunidades, chablis, descomposición, Pinus nigra subsp. laricio, bosque mixto, Córcega, Mediterráneo, Francia. 

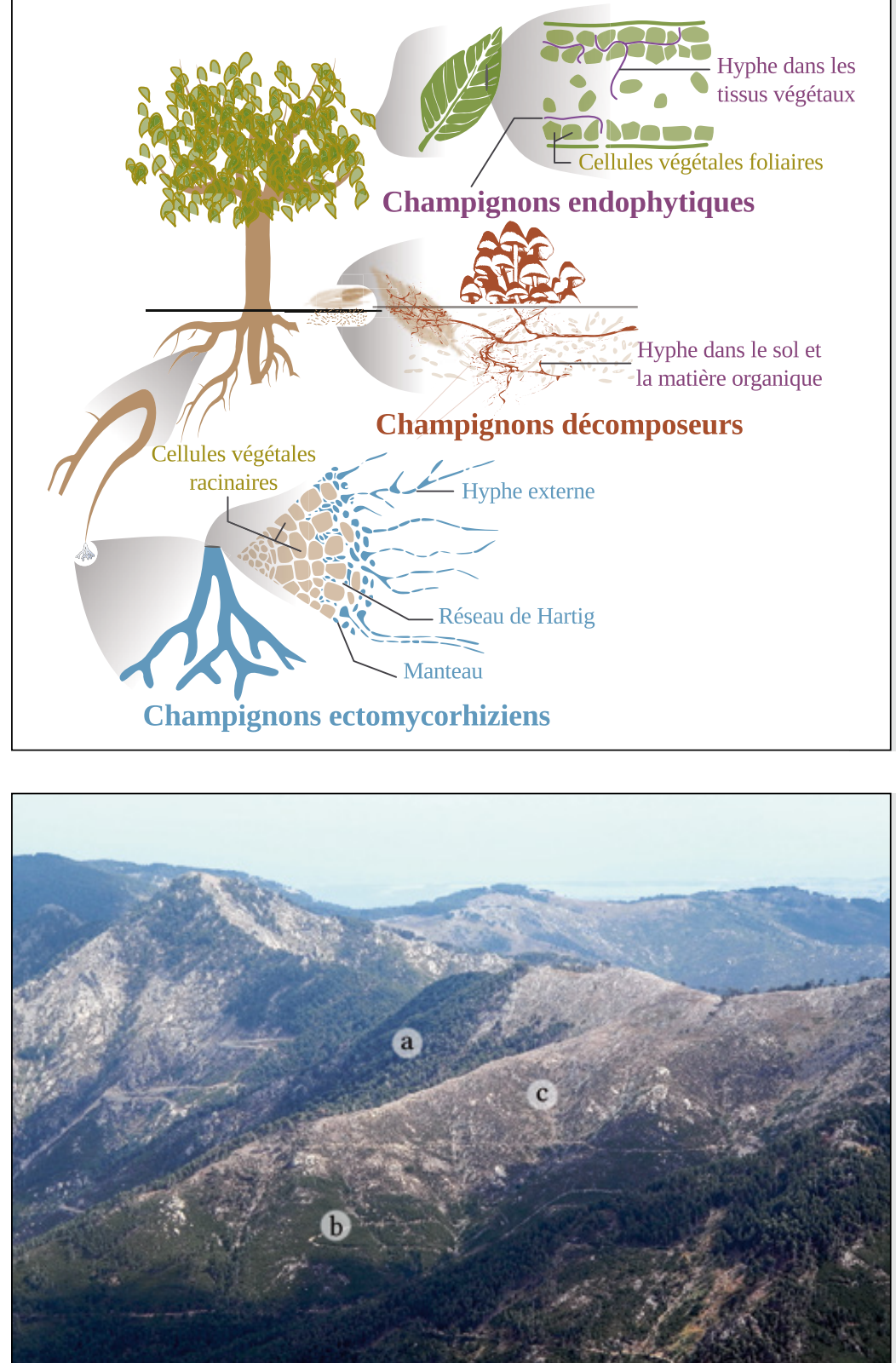

Grade et diplôme : Docteur en sciences de l'École Pratique des Hautes Études. Université : École Pratique des Hautes Études, France.

Date de soutenance : 18 novembre 2016.

Direction et encadrement : C. CARCAILLET (Directeur d'études EPHE, France) et F. RICHARD (Professeur des Universités, Université de Montpellier, France). Composition du jury

Membres : P. CHOLER (Chargé de recherche CNRS, LEA, UMR 5553 CNRS, Grenoble, France), T. CURT (Directeur de recherche IRSTEA, UR EMAX, Aixen-Provence, France), A. Dahlberg (Professor at the Swedish University of Agriculture Sciences, Uppsala, Sweden), F. MÉdAIL (Professeur à AixMarseille Université, IMBE, UMR 6372, Aix-en-Provence, France), E. THÉBAULT (Chargée de recherches CNRS, IEES, UMR 7618, Paris, France).

Langue de rédaction : français.

Accès au manuscrit : http://www.theses.fr/2016ephe3066/document https://hal.archives-ouvertes.fr/tel-01578827/document

Contact : Université de Montpellier, 163 rue Auguste Broussonnet, 34090 Montpellier, France.

adrien.taudiere@zaclys.net http://adrientaudiere.github.io/
Figure 1.

Illustration des trois guildes fongiques étudiées dans ce travail de thèse.

The three fungal guilds studied for this thesis.

Ilustración de los tres gremios de hongos estudiados en esta tesis.

\section{Photo 1.}

Forêt de pin laricio (Pinus nigra subsp. laricio) autour du col de Sorba (Corse, France) en 2015, 15 ans après les feux importants de l'année 2000. On peut distinguer trois types de paysages : (a) des zones non détruites par le feu avec des arbres adultes, (b) des zones de régénération constituées uniquement de jeunes arbres et (c) des zones où la régénération est quasi inexistante, identifiables par le grand nombre de troncs d'arbres blancs au sol.

Laricio pines (Pinus nigra subsp. laricio) around the Sorba Pass (Corsica, France) in 2015, 15 years after the major forest fires of 2000. Three types of landscapes are shown: (a) areas not destroyed by fire, with adult trees, (b) regeneration zones consisting solely of young trees, and (c) areas where regeneration is almost non-existent, identifiable by the large number of white trunks on the ground.

Bosque de pino laricio (Pinus nigra subsp. laricio) alrededor del Paso de Sorba (Córcega, Francia) en 2015, 15 años después de los grandes incendios del 2000. Se pueden distinguir tres tipos de paisajes: (a) áreas no destruidas por el fuego con árboles adultos, (b) áreas de regeneración constituidas únicamente por árboles jóvenes, y (c) áreas donde la regeneración es casi inexistente, identificables por el gran número de troncos blancos en el suelo.

Photo A. Taudière 